\title{
Multi-Stakeholder and Multi-Level Interventions to Tackle Climate Change and Land Degradation: The Case of Iran
}

\author{
Farshad Amiraslani ${ }^{1, *}$ (1) and Arnaud Caiserman ${ }^{2}$ \\ 1 Department of RS and GIS, Faculty of Geography, University of Tehran, Vesal Shirazi Street, \\ Tehran 1417466191, Iran \\ 2 Department of Geography, University of Jean Moulin Lyon 3, 7 Chevreul Street, 69007 Lyon, France; \\ arnaudcaiserman@gmail.com \\ * Correspondence: amiraslani@ut.ac.ir; Tel.: +98-21-6111-2899
}

Received: 16 April 2018; Accepted: 12 June 2018; Published: 13 June 2018

\begin{abstract}
Iran faces environmental challenges such as erosion and extreme events, namely droughts and floods. These phenomena have frequently affected the country over the past decades and temperature rise has led to a more challenging situation. Iran started to implement national and provincial policies in the 1950s to cope with these phenomena. To provide an overview of Iran's efforts to tackle land degradation and climate change, this paper examined through literature since 2000 the stakeholders' policies, their interventions and obstacles to the mitigation of these environmental challenges. Government, non-governmental organizations (NGOs), and international projects have been the primary actors. Erosion-sensitive soil plantation, drought-resistant seeds, and water-saving irrigation systems were the main interventions of these policies. However, the research stresses the lack of coordination between these stakeholders, and the absence of a comprehensive database that could enable climate change to be tackled better in the future.
\end{abstract}

Keywords: Iran; land degradation neutrality; climate change; governance; desertification; Sustainable Development Goals (SDGs)

\section{Introduction}

During the last six months of 2015, the world witnessed a series of important global summits on the growing challenges facing the Earth. The Sustainable Development Goals (SDGs) were adopted as the successor to the Millennium Development Goals in September 2015 and aimed to tackle (among other things) key issues such as human wellbeing, biodiversity loss, land degradation, and climate change. During October 2015, parties to the United Nations Convention to Combat Desertification (UNCCD) gathered in Turkey and built on the SDG commitments, formulating a comprehensive multi-year work plan which included movement towards carbon neutrality and land degradation neutrality. In December 2015, a historic climate deal was reached by the parties to the United Nations Framework Convention on Climate Change (UNFCCC), seeking to tackle climate change at a faster pace and with more tangible results. Together, these efforts mark an important point in time in tackling these interlinked challenges and also highlight the timeliness of their further investigation.

Land degradation is one of the important drivers of many social, ecological, and economic complications, especially in developing countries. Many local conflicts exist around current land use, even if it is not being degraded as shown in Switzerland and Romania [1]. The degradation of lands would worsen these conflicts. Therefore, the discretion of policies to manage land degradation appears as a key feature of investigation. Such complications include food insecurity [2], conflict and vulnerability [3], poverty [4], and the loss of ecosystem service values [5]. At the same time, 
climate change presents further challenges, particularly in dryland countries where water is already scarce, rainfall is variable and livelihood options are limited. Stringer and Reed [6] highlighted the need to examine land degradation and climate change issues together in order to develop more resilient solutions to both problems. Climate change and land degradation are highly interlinked. Hence, climate change can lead to desertification and the abandonment of lands such as farms. Therefore, tackling climate change means mitigating desertification and these two challenges cannot be managed separately. They noted the opportunities for synergy in actions, whereby steps taken to reduce land degradation and rehabilitate degraded areas can also contribute to climate change mitigation and adaptation.

Research and environmental policies are currently being conducted in order to better understand and enhance solutions aiming to tackle the dual challenges of climate change and land degradation, and to create an enabling policy environment for win-win actions. This makes research that considers efforts to address these problems at the country level particularly valuable and able to provide important insights for other locations.

Through the literature and field interviews, this paper analyzed the policies and activities in Iran in order to assess the extent to which it is tackling land degradation and developing an enabling environment for addressing climate change. The empirical analysis of governance and interventions provides a useful theoretical frame or a "conceptual map" [7] (p. 23) to understand the impacts of their policies and their relevancy [8]. Moreover, this paper aimed to improve the readiness of environmental policies in Iran. The readiness of policies can strengthen its legitimacy [9] and make its analysis more constructive. Using Iran as a case study, this paper shows options and features for arid and semi-arid countries in the Middle East which face similar environmental challenges. This research is a first attempt at assessing the current status of the country in tackling both land degradation and climate change and explores possible initiatives for the country over the long term. It specifically asks: (1) who are the key stakeholders in tackling land degradation and climate change in Iran and in establishing relevant information flows and communication channels? (2) What sort of policies, laws, and interventions have been employed to tackle land degradation and climate change from the 1950s to date? And (3) what are the main obstacles to anti-desertification and climate change interventions in Iran?

Iran ratified the UNCCD in 1996 and has been involved in many land restoration and rehabilitation activities to date. Cross-sectoral cooperation and public participation in land management have evolved gradually over the last two decades, beginning much earlier than in neighboring countries. Such governance can strengthen the relationship between decision makers and local stakeholders [8]. The cross-sectoral cooperation implies that decision makers are impartial and this characteristic should not be perceived as a weakness of the different stakeholders [10]. Moreover, cross-sectoral approaches can foster the sharing of information, research projects, and partnerships [11] to cope with environmental issues despite its large scale such as in Iran. Nevertheless, such efforts are not straightforward and require cross-sectoral coordination [2], multi-stakeholder engagement [12], and the harmonization of environmental and agricultural policies [10]. Indeed, the interdisciplinary approach to environmental issues ensures an efficient response to tackle specific problems on various scales and with different stakeholders [11]. Nonetheless, other studies have stressed the necessity to use direct policies such as lobbying and legislative intervention to ensure the efficient governance of resources [13]. In his conclusion, Imperial [13] underlined a recurrent misunderstanding about collaboration, often considered as "a magical elixir that will cure all governance problems". The leadership of decision- and policy-makers remains important and essential in the collaboration process for tackling environmental issues $[7,14]$.

The first section of the paper provides a background on land degradation and climate change in Iran. The materials and methods considered in this research are then set out. The results section then presents information on each of the three research questions in turn. The paper then concludes with remarks on possible gaps and ways forward that have been identified for the country. 


\section{Background}

Like other developing countries, Iran is now facing climate change and its implications (Table 1). Moreover, anthropogenic factors (e.g., urbanization, deforestation, over-exploitation of water resources) have compounded soil and land degradation [15]. The country has been ranked as one of the top 20 most vulnerable countries to climate change according to selected environmental and economic indicators [16]. The predictions of hydrological models, using data extracted from 37 climate stations across the country from 1980-2002, suggest a drier situation for dryland parts of the country with more floods for wet areas for during 2010-2040 and 2070-2100 [17]. Moreover, neural network models using data recorded from 1985-2008 suggest an increase of 0.26 degrees centigrade for the country in 2018 (using the base year of 2008) [18].

Table 1. Climate change projections at various spatial scales in Iran.

\begin{tabular}{cccc}
\hline Climatic Feature & Temporal Scale & Spatial Scale & Source \\
\hline A decline of 3.5 mm in annual mean rainfall & $\begin{array}{c}\text { 25 years } \\
(1979-2004)\end{array}$ & Yazd province (central Iran) & {$[19]$} \\
\hline Significant reduction in summer rainfall & $\begin{array}{c}55 \text { years } \\
(1951-2005)\end{array}$ & Country level & {$[20]$} \\
\hline Decreasing trend in aridity index in southern basins & $\begin{array}{c}50 \text { years } \\
(1955-2005)\end{array}$ & Arid and semi-arid basins & {$[21]$} \\
\hline $\begin{array}{c}\text { Changes in climatic extreme events (e.g., increase in } \\
\text { warm nights, hot days, maximum wind speed) }\end{array}$ & $\begin{array}{c}30 \text { years } \\
(1977-2007)\end{array}$ & All 12 southern and northern \\
coastlines & {$[22]$} \\
\hline Decreasing in spring and summer precipitation & $\begin{array}{c}58 \text { years } \\
(1951-2009)\end{array}$ & Country level & {$[23]$} \\
\hline $\begin{array}{c}\text { Changing trends in near-surface wind speed (the } \\
\text { frequency of the upward trends was more pronounced) }\end{array}$ & $\begin{array}{c}30 \text { years } \\
(1975-2005)\end{array}$ & Arid and semi-arid areas & [24] \\
\hline
\end{tabular}

Arid and semi-arid areas cover $80 \%$ of Iran and are home to $77 \%$ of the total urban population living in 17 provinces [25]. Many industrial and economic centers are located in these areas. With a land area of about 1.65 million $\mathrm{km}^{2}$, the country has diverse landscapes and climatic zones. About $20 \%$ of the land is covered by deserts, while rangelands cover $55 \%$ and forests $8 \%$; other land uses include agriculture (11\%), and industrial and residential areas (6\%) [26]. About $10 \%$ of the country's area is considered to be protected areas [17]. Climatically, Iran is a country with arid and semi-arid climates and with the exception of the narrow borders in the north, the rest of the country receives low and erratic rainfall (Figure 1). There is a large variation of rainfall both spatially and temporally [27]; from very humid in north with high precipitation (up to $1200 \mathrm{~mm}$ per year) to relatively dry in the south (less than $300 \mathrm{~mm}$ ); and the climate varies from very dry in the east to sub-humid in the west. The central part of Iran is normally considered as desert with very hot and very low precipitation $(<100 \mathrm{~mm} /$ year). High mountain ranges located in the northern and western parts have impeded humidity from reaching the center [27].

Fars Province, a pivotal agricultural region in Central Iran has, for instance, experienced frequent droughts between 2003 and 2011, leading to the degradation of agricultural resources [30]. Moreover, increasing temperatures will affect the production capacities of the agricultural sector over the next decade [30]. Furthermore, on a national scale, evapotranspiration could increase, especially in the north of Iran, increasing water needs on account of climate warming [31]. Implications of such changes driven by climate change are observed in the form of less longevity and more dryness of vegetation, altered soil moisture, and the formation of scattered vegetation mosaics, thus exposing the soil to more erosion. Model results estimate an increase in on-site and off-site soil erosion in response to various future climate change scenarios [32]. 


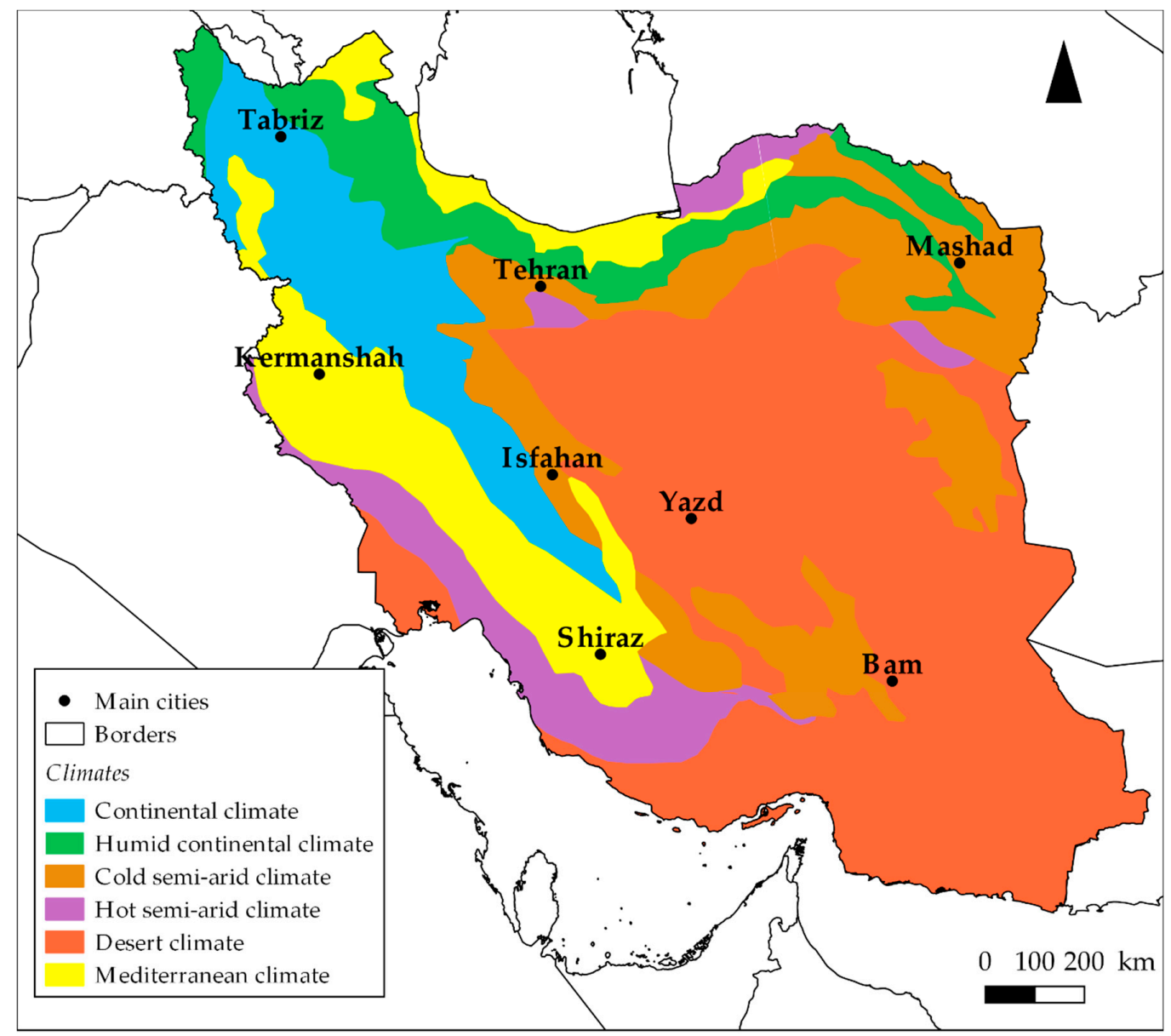

Figure 1. Köppen classification of climate in Iran (Source: Chelsa Climate Biovariables [28,29]).

In Iran, over 2 million hectares of degraded lands have been rehabilitated since the 1950s [33], with scope for even more degraded land to be targeted in line with commitments to the global land degradation neutrality target (LDN). Iran is also a Non-Annex I Party to the UNFCCC. It ratified the UNFCCC in 1996 and submitted its Second National Report in 2010 as well as its Intended Nationally Determined Contribution (INDC) in 2015 in preparation for the Paris UNFCCC Conference of the Parties. The country is gradually moving toward clean energies, improving the fuel efficiency of power plants, buildings and vehicles as well as increasing carbon sequestration through investment, promotion, field activities, and public awareness. However, its greenhouse gas emissions continue to rise [34]. The scope for rehabilitating a larger area of land, combined with the need for the country to develop new mitigation and adaptation options make it a useful case study in this research.

Urbanization brings problems of soil sealing, which can drive important changes to the gas exchanges between the soil and the atmosphere. Urbanization has also exerted more pressure on the water sector and increased the deforestation trend [33,35]. Reduced tree cover nevertheless affects the mitigation capacity of Iran's forests. Moreover, desertification is affecting more than half of the country's provinces (Iran has 17 provinces) scattered mostly in the central and eastern areas [33].

Desertification was recognized as an environmental challenge in the early 1930s in Iran [25], before the recognition of climate change. To tackle desertification, the Ministry of Agriculture created a "Soil and Water Conservation Committee" in the 1950s and other structures included in the Forest Rangeland and Watershed Management, to stabilize sand dunes [36]. In the 1970s, the Department of Environment (DoE) was created to manage environmental conservation projects in Iran [37]. Several anti-desertification projects were conducted in the 1960s such as dune stabilization, 
oil mulching or runoff control. In particular, since the year 2010, the environment has become a central concern in Iran, especially with water shortages that the government aims to tackle by proposing and implementing several policies [38].

\section{Materials and Methods}

No comprehensive census of stakeholders and environmental interventions is available, so we were reliant upon document analysis, field interventions and a literature review. Overall, 41 published articles (in English from the Web of Science) and unpublished materials and manuscripts (in Persian from Iranian studies, personal communications and interviews in the field detailed in Table 2), spanning the period 2000-2016 were utilized in the analysis (Table 3). Interviews were conducted in different parts of Iran within the framework of different projects. Farmers and authorities of the Fars, Khorasan and Sistan-Baloochestan provinces were selected since these provinces are strongly affected by desertification and climate change. In Fars Province, only farmers were interviewed on water management. Interviewed farmers were randomly selected on the field. The year 2000 is a key baseline year as it marks the time at which participatory natural resource management started to be given a high priority at a national level in Iran. Most national information and documents are produced in Persian and, therefore, either incomprehensible or less accessible for international readers. Persian documents were nevertheless included alongside the English language publications in order to augment the knowledge base available for analysis. On the policy side, two major policy documents and booklets (in Persian) were considered: Iran's National Action Programme to Combat Desertification (NAP) [26] and Strategic National Plan [39]. The NAP is a national policy document focusing on combating desertification and the mitigation of drought and was prepared through cross-sectoral cooperation. The latter is an analytical document that focuses on land sustainability and knowledge gaps in Iran. We also drew on a report published by the UN that investigated a major drought event [40]. The latest Country Report on climate change [41] and the country's Intended Nationally Determined Contributions (INDC) were also assessed.

Table 2. The structure of interviews conducted between 2012 and 2018.

\begin{tabular}{|c|c|c|c|c|}
\hline Stakeholder & Location & Year & Themes of Interviews & Context of Interviews \\
\hline $\begin{array}{l}\text { Farmers/local } \\
\text { authorities }\end{array}$ & $\begin{array}{l}\text { Several villages in South } \\
\text { Khorasan province, East of Iran }\end{array}$ & 2012 & $\begin{array}{l}\text { Participatory natural } \\
\text { resources management }\end{array}$ & $\begin{array}{c}\text { Carbon Sequestration } \\
\text { Project }\end{array}$ \\
\hline $\begin{array}{c}\text { Farmers/local/ } \\
\text { national } \\
\text { authorities }\end{array}$ & $\begin{array}{c}\text { Several villages in Kermansh } \\
\text { (West of Iran), } \\
\text { Sistan-Baloochestan provinces } \\
\text { (East of Iran), Yazd (Central } \\
\text { Iran) provinces }\end{array}$ & 2013 & $\begin{array}{l}\text { Local livelihood; } \\
\text { income-generating } \\
\text { activities in rural areas; } \\
\text { integrated watershed } \\
\text { management }\end{array}$ & $\begin{array}{l}\text { Middle East and North } \\
\text { Africa Regional } \\
\text { Development for } \\
\text { Integrated Sustainable } \\
\text { Development } \\
\text { (MENARID) Project }\end{array}$ \\
\hline Farmers & $\begin{array}{l}\text { Marvdasht (Fars province in } \\
\text { Central Iran) }\end{array}$ & 2018 & $\begin{array}{l}\text { Water management, } \\
\text { agriculture }\end{array}$ & $\mathrm{PhD}$ research \\
\hline
\end{tabular}

Table 3. Literature data used for review (Cited references in this tables are presented in the references list).

\begin{tabular}{cccccc}
\hline \multicolumn{3}{c}{ In Persian } & \multicolumn{2}{c}{ In English } \\
\hline Reports & Papers & Others & Reports & Papers & Others \\
\hline$[26,39]$ & {$[19,42-44]$} & {$[45,46]$} & {$[40,41]$} & {$[15,17,18,20-25,27,30,31,33,35,36,38,47-59]$} & {$[34,60]$} \\
\hline
\end{tabular}

The compilation of references was based on keywords and the dates of publication (after 2000). From these references, we have identified and classified the stakeholders who have played a role in environmental policies in Iran. Frequently quoted stakeholders (at least once) were considered as the most significant in this regard. In the second phase, their interventions were compiled, analyzed, and classified according to the field of action (anti-desertification, water management, 
agricultural strategies, biodiversity conservation, forest management and protection, involvement of local communities). The obstacles of these interventions are assessed according to the interventions' limitations and to recurrent barriers, often evoked in the corpus. Frequently quoted stakeholders, interventions and obstacles are assumed to be the most significant on the ground at a national level since the references are not chosen in one specific region of Iran, but cover a national level. There are too many local interventions in Iran on regional scales for this paper to claim to list individually. To synthetize these obstacles, this research used an evaluation grid by counting the number of occurrences of similar obstacles in the references. The following sections report on the findings from our analysis tackling each research question in turn.

\section{Results}

4.1. Who Are the Key Stakeholders Involved in Tackling Land Degradation and Climate Change and How are Relevant Information Flows and Communication Channels Established?

Stakeholder analysis was based on the assessment of the current roles of each major institution as part of efforts to address land degradation and climate change. Currently, there are several public institutions that coordinate and manage efforts to tackle climate change and land degradation in Iran. These organizations are summarized in Table 4.

Table 4. Stakeholders involved in land degradation and climate change in Iran.

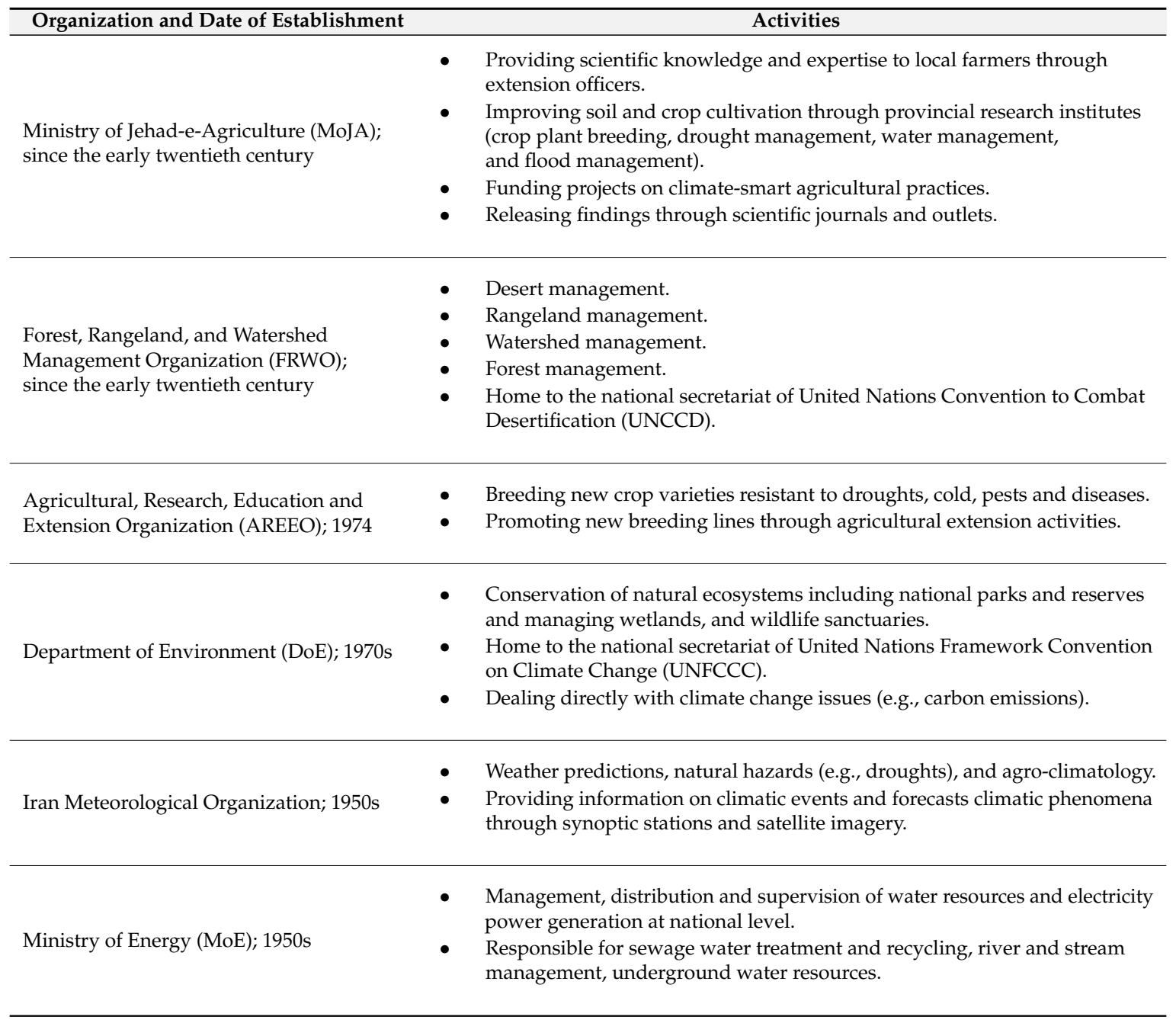


Table 4. Cont.

\begin{tabular}{|c|c|}
\hline Organization and Date of Establishment & Activities \\
\hline $\begin{array}{l}\text { Ministry of Science, Research and } \\
\text { Technology; 1930s }\end{array}$ & $\begin{array}{l}\text { - Training through providing courses and subjects related to climate change, } \\
\text { combating desertification and environment, land management and climate } \\
\text { change at various levels: e.g., MSc (combating desertification and } \\
\text { watershed management). } \\
\text { - Generating knowledge on the aforementioned fields through } \\
\text { research facilities. }\end{array}$ \\
\hline International organizations & $\begin{array}{ll}\text { - } & \text { Funding of national projects. } \\
\text { - } & \text { Partnerships by providing expertise on relevant fields. } \\
& \text { Co-production of data and reports. }\end{array}$ \\
\hline $\begin{array}{l}\text { Non-governmental organizations (NGOs) } \\
\text { (see text) }\end{array}$ & $\begin{array}{l}\text { - } \quad \text { Holding workshops with local stakeholders. } \\
\text { - } \quad \text { Participatory resources management. } \\
\text { - } \quad \text { Biodivementation of projects. } \\
\text { - } \\
\text { Agro-economic researches. }\end{array}$ \\
\hline Others & $\begin{array}{l}\text { - For instance, at local level, municipalities are involved in planting plant } \\
\text { species tolerant to rising temperature, utilization of pressurized irrigation } \\
\text { systems, and expansion of greenery spaces in urban areas. }\end{array}$ \\
\hline
\end{tabular}

\section{- Government}

After reviewing the references, the most cited stakeholder for environmental interventions was the government (Figure 2). Indeed, numerous services and organizations of the government of Iran are involved and lead the current policies to tackle land degradation and climate change. The Ministry of Jehad-e-Agriculture (MojA); the Forest, Rangeland, and Watershed Management Organization (FRWO), the Agricultural Research Education and Extension Organization (AREEO), and the Ministry of Energy (MoE) were frequently quoted in the references, mainly in the scientific papers and official reports. In addition, the government seems to be the main investigator and investor of these plans and policies in Iran. This investment of the government in environmental challenges was begun in the 1970s by developing national policies and making interventions which evolved into calibrated plans at the provincial scale by the end of the 20th century [49].

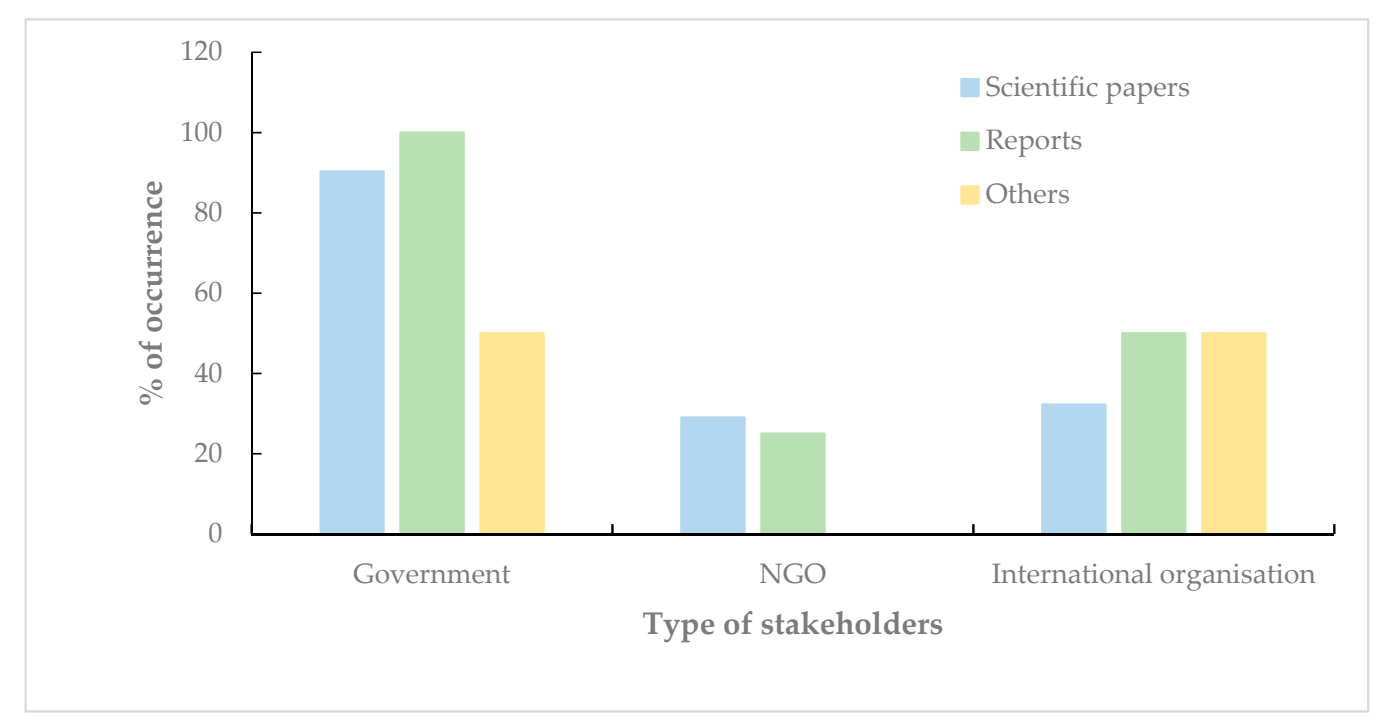

Figure 2. Occurrence of quoted stakeholders per reference type. 
- International stakeholders

Since the 1970s, the country has constantly joined international environmental treaties and programs and mainstreamed environmental concerns and plans in its five-year National Developmental Plans. A direct link has been found between the international treaties and major political decisions regarding environmental issues in Iran [59]. The occurrence of international organization quotations in the references was lower than the government quotations. However, one should not underestimate the role of these stakeholders in Iran. Several international organizations such as the Food and Agriculture Organization (FAO), United Nations Development Programme (UNDP) [43], United Nations Educational, Scientific and Cultural Organization (UNESCO), and Tehran Processes Secretariat for Low Forest Cover Countries are involved as part of numerous international projects carried out in Iran. These projects have mainly been quoted by scientific papers and reports which have international appeal (Figure 2).

- Non-Governmental Organizations (NGOs)

Table 3 revealed a dominance of large public and governmental organizations involved in land management and climate change. Since 2000, however, NGOs and the private sector have been more actively involved. The NGOs, such as Cenesta, Earth Watchers Center, Green Front of Iran or Iranian Society of Environmentalists (IRSEN), among the largest organizations in Iran, despite their presence on local scales, are less quoted as a meaningful stakeholder than the government and international organizations (Figure 2). Each group seems to have its own role with little evidence of duplication of activities in the documents analyzed. However, the lack of a coordinating body to spearhead and integrate these multiple roles in managing land degradation and climate change is potentially problematic as opportunities for a win-win strategy could be missed.

\subsection{What Sort of Interventions Have Been Employed to Tackle Land Degradation and Climate Change from the} 1950s to Date?

Since the 1950s, national efforts have been made to reclaim degraded lands. These efforts have demanded great financial and human capital but have resulted in modest achievements. Iran was reported to be one of the top 10 countries in forest plantation development in the world in 2001, as $1 \%$ of the country's area has been planted using drought-tolerant and native species [48].

Efforts to reduce the impacts of land degradation in arid and semi-arid areas have helped local communities to cope with changing local climatic situations [61]. These efforts have been implemented in various forms: while some have focused on natural parameters (e.g., water resources management) others have focused on human aspects (e.g., capacity-building of local people). Infrastructure has been preserved through the implementation of projects such as the establishment of forest plantations or windbreaks by the Ministry of Jehad-Agriculture. The fields of actions are quoted in the following sections, organized according the main interventions quoted by literature from Table 3.

- Anti-desertification

Much of the land area in Iran's 17 desertified provinces is covered by shifting sand dunes. It is estimated that over 1.5 million hectares of shifting sand dunes still exist [39]. Most of these dunes have resulted from the degradation of topsoil in agricultural lands and rangelands. However, recurring droughts, high temperatures, and increasing evapotranspiration, possibly linked to climate change, challenge the establishment of vegetation on these sand dunes. These shifting dunes impact on the normal daily activities of local people, either by affecting farmlands or causing ophthalmic or respiratory diseases. Since the 1950s, the FRWO has employed diverse measures to stabilize these sand dunes and prevent their encroachment into residential areas or infrastructure. Seedling plantations, seeding, and similar measures have been employed by the FRWO with the participation of local communities and NGOs [33]. The dominant plant species is Haloxylon, a native shrub that is resistant to drought and windy climates, but does not have any edible uses for humans. This species can 
store $61.5 \mathrm{ton} / \mathrm{ha}$ carbon across a 0-30 cm soil depth in an arid environment [46]. Once established, these seedlings need additional support such as watering, manuring, pruning, and protection from grazing animals. Established plants will become self-sustained, independent, and be able to survive through harsh weather after 3-4 years depending on climatic conditions and vigorous seedlings. Nearly two million hectares of such sparse forest plantations have been established since the 1950s. Additionally, a national survey indicates that $9000 \mathrm{~km}$ of roads and railroads, $9800 \mathrm{~km}$ of rivers and water canals, 600,000 ha of arable lands, and so many others (airport, school, hospitals) have been preserved as a result of anti-desertification plans in Iran since the 1950s [42]. As a matter of fact, a recent study assessed the contribution of these anti-desertification plans in Iran's GDP and found that these plans indirectly contribute to $3.75 \%$ of GDP [61].

\section{- Knowledge-sharing}

The multi-scale spread of stakeholders involved with addressing land degradation and climate change and a lack of overall coordination in the Iranian context means it is imperative that information is well managed and knowledge is exchanged between the different groups. A National Soil Map was realized in 1964 to classify soil according to environmental factors. Divided into six classes, this document maps the agricultural potential of soil regarding the level of salinity and erosion limitations [42]. More recently, an increase in scientific publications, patent registration, and engineering initiatives has been documented [50], especially over the past two decades. Similarly, a recent surge in the number of science and technology institutions has been instrumental in generating knowledge and databases, especially relating to land degradation and land management. For instance, in cooperation with universities, a national map was prepared for the identification of critical foci to wind erosion in 2004. It has acted as a key source for FRWO authorities to implement anti-desertification activities. However, not all scientific findings have been directly utilized in such a manner, and similar initiatives/maps relating to the climate change arena did not emerge in our analysis. This suggests that while Iran has been tackling land degradation and desertification since the 1950s, the information bank on climate change within the country is less well developed and is in need of improvement.

- Water management

Water is managed by MoE and MoJA in Iran and has always been a key factor in shaping civilization during history; in particular, it is a pivotal and decisive element of development in dryland countries such as Iran. Contemporary Iran faces a water-shortage crisis [38], thus the country has devised on-the-ground measures to control surface water through the construction of large-scale dams, check dams, turkey nests, small pits, small-scale dams, earth dams, micro-dams, open water harvesting, and other water-diverting structures. Flood mitigation techniques have also been implemented to enrich the groundwater. Through these projects, more run-off water is being harvested and utilized for planting, seeding, or sawing plants. In particular, these run-off control measures are effectively controlling water sources in sloping hills or plains where establishing plants and retaining water are difficult. In addition, much of the water (over $90 \%$ ) is absorbed by the agriculture sector through irrigation practices [56] and the country has invested in pressurized irrigation systems (e.g., drip irrigation) to distribute water in farms more efficiently. Nonetheless, farmers interviewed in Khorasan, Fars and Sistan-Baloochestan stated that they still use a furrow irrigation system, which greatly hampers irrigation efficiency on account of water evaporation (Table 2).

- Agricultural strategies

Current models predict significant economic damage to agriculture in developing countries as a result of climate change and, thus, adaptation is regarded as vital [62]. Even wild endemic plant species are predicted to be endangered by rising temperatures as a result of climate change [51]. Climate models based on weather data from 1968 to 2000 at 36 weather stations, suggest a severe reduction in the number of agro-environment zones in Iran from 10 in 2006 to 8 and 7 in 2025 and 2050, respectively [51]. Elsewhere, Abbaspour et al. [54] ran hydrological models for 506 sub-basins 
across Iran and found that climate change will significantly impact irrigated wheat production in dry zones. Thus, breeding strategies to introduce drought-tolerant crops are required. An established public agricultural research center from the MoJA (Seed and Plant Improvement Institute) has worked on generating new genetic lines of crop plants that are resistant to drought (or need less water for growth), resistant to pests, diseases and environmental stresses (such as salinity) as well as crops that produce more grains per hectare (high-yield crops) or can grow within a shorter period. Each province has its own agricultural research branch that works on strategic crop varieties having more endogenic eco-physiological capability. The main aim is to explore new breeding lines that can adapt to changing local climate, pests and diseases while producing more grain per hectares. In the meantime, there are several field and laboratory experiments for breeding new lines of crops that can cope with the possible detrimental impact of climate change in Iran (e.g., the cultivation of early maturing cultivars of maize) [57]. Nonetheless, most of these drought-resistant crops did not enter into regular production in Iran and remain experimental crops. Given the predicted climate change impacts on agriculture in Iran, these new breeding lines can ensure improved crop yields while sustaining native crop varieties that are resistant to droughts and which make appropriate use of soil conditions.

- Biodiversity conservation

On account of significant biodiversity, the country's conservation was strengthened by the Law for Endangered Species of Wild Fauna and Flora in 1975, and the Law for Protection of the Natural Parks, Protected Areas, and Sensitive Areas ratified by the Parliament in 1975 [60]. A wide range of indigenous plant species are utilized in anti-desertification plans. A greater number of shrub and annual plant species have been introduced and cultivated in degraded lands in arid and semi-arid areas when compared to the early days when anti-desertification projects started in Iran in the 1950s [25]. In 2005, a total of 37 cultivated plant species were identified in anti-desertification projects as compared to 25 species in 2000 and a handful in the past [44]. This flora diversification, in comparison with monoculture systems, has reduced pest and disease plagues and improved biodiversity and adaptability to climate change. Such plant variation can also ensure the establishment of vegetation on sand dunes and reclaimed lands, especially during times when one plant variety is infested by certain plagues.

- Forest management

It is vital that tree-planting efforts are not undermined by emissions from the energy sector. Over the last century, the consumption of fuel wood in Iran has reduced as a result of oil and gas substitution [33]. However, oil and gas have led to increased emissions overall [34]. At the same time, the removal of energy subsidies at a national level since 2010 has provided a firm ground for exploring and investing in renewable energy sources and the $\mathrm{MoE}$ is in charge of research. Land management measures in Iran are fortified and supported by national laws, market incentives, and public participation, particularly in local communities. Regarding laws and regulations on the conservation of the environment, the country has a relatively good standing in Asia. As an example, Iran launched its first attempts to assess and conserve forest resources a century ago [58]. The early legislation attempt was made to form a Game Council in the 1950s to focus on wildlife protection at a national level [35].

- Involvement of local communities

Current laws and regulations mandate any national development plans to be first endorsed by environmental authorities. More national authorities (e.g., members of parliament) are involved in planning, managing, and legislating environmental disasters (both natural and man-made disasters). Overall, the Iranian national laws/plans relevant to tackling land degradation issues are outlined in Table 5. 
Table 5. The laws and plans relevant to land degradation at national level in Iran *.

\begin{tabular}{ll}
\hline Law/Plan & Remarks \\
\hline Constitution Law & $\begin{array}{l}\text { Article } 50 \text { of this law deals with the preservation of } \\
\text { environment as a 'public duty'. }\end{array}$ \\
\hline Five-year National Development Plan & $\begin{array}{l}\text { These plans generally comprise several budget chapters } \\
\text { specifically addressing those environmental issues that must } \\
\text { be tackled within the subsequent 5-year timeframe. }\end{array}$ \\
\hline & $\begin{array}{l}\text { Prepared through the National Secretariat of the Convention } \\
\text { for Combating Desertification located within FRWO and } \\
\text { submitted to the UNCCD in 2004, and has been revised several } \\
\text { times since then. }\end{array}$ \\
National Action Program to Combat & $\begin{array}{l}\text { The core of this plan is to involve local people from designing } \\
\text { to implementing stages to ensure the sustainability of projects } \\
\text { that tackle land degradation [39]. }\end{array}$ \\
& $\begin{array}{l}\text { Prepared and ratified over half of century ago (1950s) as the } \\
\text { earliest contemporary policy document. } \\
\text { The law considered a wise intervention and exploitation of } \\
\text { rangelands and forests in the country. }\end{array}$ \\
\hline Comprehensive Natural Resources & management Law
\end{tabular}

* Laws mentioned above are further covered by the overarching goals of Article 50 of constitution Law that emphasizes improved environmental conditions for all citizens.

The involvement of local communities in natural resource management (including land reclamation) and climate change adaptation plans has been gradually institutionalized in the country over the last decade. This approach has helped to assure the sustainability of the projects and lowers the costs of the establishment and maintenance of projects [39]. Some successful projects carried out by the FRWO are acting as demonstration or pilots to draw local public attention. A well-known project is the 'Carbon Sequestration Project' funded by Iran, Global Environment Facility (GEF), and UNDP. It was started in a south eastern province in 2003 and the first phase was completed in 2009. Since then, the project has gained further funding and continued for a second term (2009-2015). It is now being practiced in several provinces. The core concept of this project is to involve vulnerable rural community members in coping with the impacts of climate change through schemes such as the expansion of forest plantations, alternative livelihoods, promotion of renewable energy sources (e.g., solar panels), and capacity-building initiatives (training workshops) [58]. Given that the area had been affected by land degradation in the past, the project has improved carbon stocks in the soil and prevented further soil erosion. The project has specifically targeted marginal rural women and the youth. These groups were illiterate, poor, non-skilled, and heavily reliant upon the natural resource base, engaging largely in agriculture and pastoralism.

\subsection{Identification of the Main Obstacles to Anti-Desertificaton and Climate Change Interventions in Iran}

The previous sections have addressed research questions 1 and 2. In this section, we discuss research question 3 and evaluate whether efforts to date in Iran met significant obstacles. It appears that the efficiency of these interventions and actions are undermined by four different factors. Figure 3 illustrates the distribution of obstacles quoted in the references. 


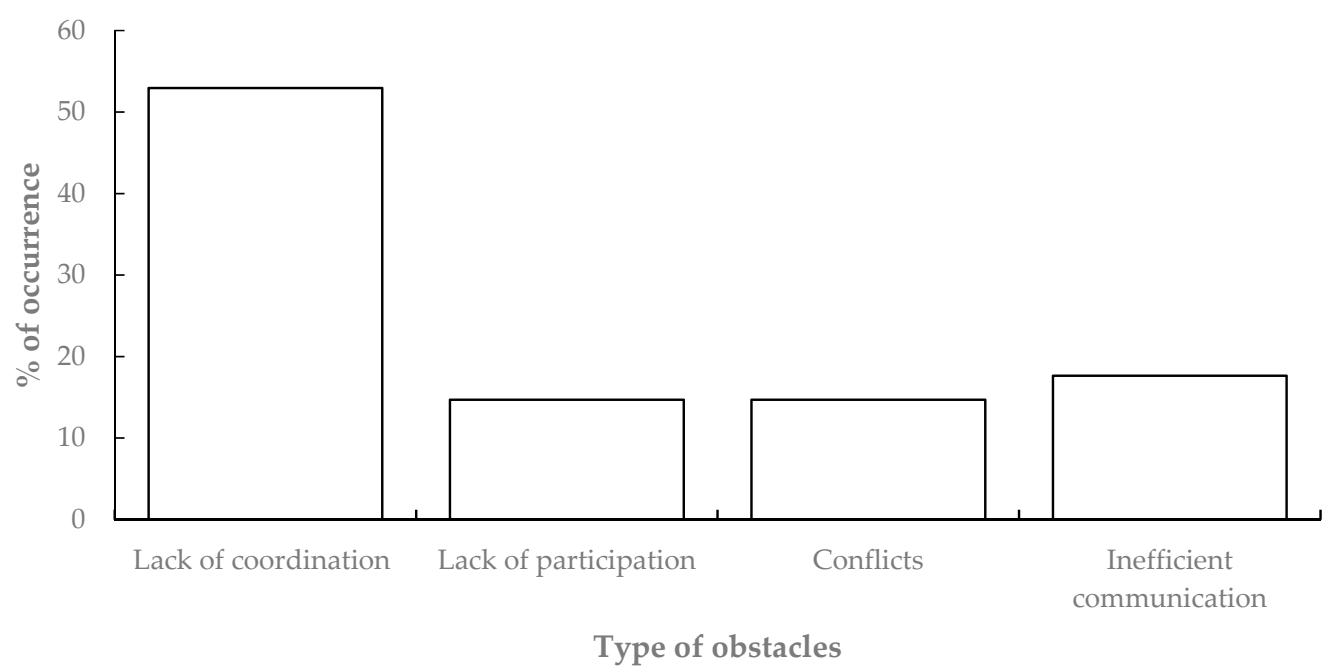

Figure 3. Occurrence of quoted obstacles to policies' efficiency in the references.

- The lack of coordination

One of the most cited obstacles that interferes with the efficiency of the interventions is the lack of coordination (Figure 3). In the references, several organizations that were independently addressing efforts related to climate change and land degradation issues in Iran have been mentioned. However, the goals of these institutions are not well aligned across sectors and scales. At the moment, there is no platform to specifically coordinate these initiatives and no attempts have been made to establish any such national body to gather, update, distribute, and reorganize information at the national level. The higher the adaptive capacities of people to cope with the climate-driven phenomena, the better the chances of societies to become resilient as reflected in community adaptation outcomes [63]. Climate change adaptation and sustainable land management measures need information to be shared with all sectors and stakeholders, but this does not seem be happening sufficiently at present $[17,25,27,42,46,47,54,55]$.

- Inefficient communication

Moreover, the establishment of effective communications is still a challenge due to the vast areas of provinces, the illiteracy of some local communities, inappropriate funding, and a lack of skilled trainers $[25,26]$. Lack of an enduring link between the FRWO and other organizations makes it very hard to coordinate land degradation projects alone, without also seeking to harness the benefits for tackling climate change. At the same time, inefficient communication between research institutes and universities with executive organizations (such as FRWO) makes it difficult to establish targeted and systematic research. The challenges we faced in finding data and information for analysis revealed a collection of mostly scattered pilot projects without feedback, cross-linkages, and lessons being learned from one project to another. While datasets and information on relevant issues have been generated in Iran over recent decades, most of the data have not been fed into capacity building nor informed project implementation. For instance, in Iran the management of grazing in national parks could be improved by providing consistent data, however a database on the "extent of the problems" of over-grazing does not exist [17] (p. 16).

- Conflicts of interest

Conflicts of interest between local communities and decision-makers were mentioned in our analysis. The conflicts are rooted in the exploitation of natural resources, whether or not they are protected. For instance, in the protected areas, Iran experiences disputes around the exploitation of wildlife, flora, or water by the locals $[17,47]$. Locals have always exploited wood for their own 
consumption while this conflicts with the essence of the laws of conservation, especially in the Central Zagros Mountains. Hence, divergent interests hamper the effective management of resources. Similar cases were reported regarding grazing in sensitive areas [55]. Shepherds are supposed to have a permit for grazing. However, the lack of control sometimes leads to numerous illegal overgrazing incidents in some protected areas such as in the Juniper Forest of Chenaran city in Khorasan Razavi province [17].

- Lack of participation and involvement

Some studies have reported the lack of public participation in developing local policies and interventions. Some anti-desertification projects have stressed failures on account of the weak participation of local communities $[17,25,36]$. In addition, farmers and local stakeholders are sometimes reluctant to participate in projects or collective organization that could hamper their access to local resources [49]. For instance, a farmer interviewed in the plain of Marvdasht (Table 2) (2018) stated: "I don't want to be in the local agricultural cooperative. I prefer to be on my own and not to depend on others". Nevertheless, the participation of local communities is known as a key feature in the success of environmental and agricultural policies, as shown through the successful protection of rivers and wetlands in Iran and beneficial incomes for communities such as jobs [49,61].

\section{Discussion and Conclusions}

In this paper, we first provided an overview of the challenges in relation to climate change and land degradation in Iran. We then listed the implemented activities that have been effective in tackling some challenges at the national level. We propounded a few questions regarding key stakeholders, public interventions, and strategies and laws that have seemed to be relevant in tackling these challenges over the past half a century. However, we discussed and demonstrated continuing challenges in relation to climate change adaptation, especially through several obstacles to these interventions. There is no doubt that the aforementioned exemplified national and local initiatives, projects and activities are not complete and comprehensive.

Furthermore, this literature review is not exhaustive. Numerous studies have been conducted but are published in Persian and access to this literature remains difficult. The authors chose some references based on their quality and intelligibility. Further reviews are necessary, especially the analysis of recent studies which could take advantage of wider implications.

Improved coordination and the involvement or participation of local communities could facilitate the provision of details of activities, better access to information and knowledge-sharing about good practices as well as help to streamline findings from research where they can inform national policies. Moreover, the involvement of local communities to tackle desertification has appeared as a key issue to sustainable development policies. Linked to this is the need to create a task group that can communicate and broadcast information to various stakeholders and beneficiaries. Public mass media (television, newspapers) would be major useful channels for the purpose of one-way communication, with the enhanced use of participatory approaches in project design and implementation providing a valuable space for two-way communication and knowledge exchange between the stakeholders.

This was the first attempt to integrate this scattered information for the sake of sharing among the beneficiaries at both the national and international levels. In addition, we hope that this review has shown major obstacles to the interventions being more efficient. Furthermore, it is hoped that the paper will help decision-makers to focus on those challenges that are not systematically known or taken into account at the decision level. The identification of obstacles to environmental challenges is necessary in order to understand why some of these interventions are not sustainable, mainly due to the lack of coordination. Therefore, the sustainability of development not only depends on the capacities of environmental managers to set up an action on the ground, but their ability to communicate and involve local stakeholders. Desertification and climate change should be seen as platforms for decision-makers to formulate new policies and interventions. Indeed, these environmental challenges are complex 
with plural facets, influenced by the combination of natural and human factors. Such a combination of challenges requires calibrating the interventions to address both of these factors. The plurality of these challenges should lead to multiple, adapted and sustainable answers. There are some lessons learned that are narrated by this paper. The government's financial investment and relevant projects have been proven to help rural communities to become empowered and self-reliant, such as workshops on renewable energy [36], or the protection of natural resources for local communities, managed by National Action Program to Combat Desertification. The employment of a diverse range of on-the-ground activities and plans with multi-stakeholders has been very effective. Like other countries, Iran is now facing climate change and its consequences. National efforts have been made to reduce the impacts of climate change in Iran over the last decades, but more attempts are still needed.

Author Contributions: F.A. developed the idea and gathered the Persian and international references while A.C. completed the reference data with comparative English studies. The analysis of the references and policies was first conducted by F.A. and A.C. pursued it with recent facts. The authors shared in writing the paper.

Funding: This research received no external funding.

Acknowledgments: We are indebted to Lindsay Stringer, University of Leeds, for her valuable comments made to the earlier version which have improved the main debate. We also appreciate the two anonymous reviewers for their constructive comments.

Conflicts of Interest: The authors declare no conflicts of interest

\section{References}

1. Hersperger, A.M.; Ioja, C.; Steiner, F.; Tudor, C.A. Comprehensive consideration of conflicts in the land-use planning process: A conceptual contribution. Carpath. J. Earth Environ. Sci. 2015, 10, 5-13.

2. Stringer, L.C.; Dougill, A.J.; Thomas, A.D.; Spracklen, D.V.; Chesterman, S.; Ifejika-Speranza, C.; Rueff, H.; Riddell, M.; Williams, M.; Beedy, T.; et al. Challenges and opportunities in linking carbon sequestration, livelihoods and ecosystem service provision in drylands. Environ. Sci. Policy 2012, 19, 121-135. Available online: https://www.sciencedirect.com/science/article/pii/S1462901112000342 (accessed on 11 May 2013). [CrossRef]

3. Okpara, U.T.; Stringer, L.C.; Dougill, A.J. Perspectives on contextual vulnerability in discourses of climate conflict. Earth Syst. Dyn. 2016, 7, 89-102. Available online: http://eprints.whiterose.ac.uk/95752/ (accessed on 1 September 2017). [CrossRef]

4. Barbier, E.B.; Hochard, J.P. Does Land Degradation Increase Poverty in Developing Countries? PLoS ONE 2016, 11, 1-12. Available online: https://www.ncbi.nlm.nih.gov/pmc/articles/PMC4864404/ (accessed on 12 February 2017). [CrossRef] [PubMed]

5. Costanza, R.; de Groot, R.; Sutton, P.; van der Ploeg, S.; Anderson, S.J.; Kubisewski, I.; Farber, S.; Kerry Turner, R. Changes in the global value of ecosystem services. Glob. Environ. Chang. 2014, 26, 152-158. Available online: https://www.sciencedirect.com/science/article/pii/S0959378014000685 (accessed on 19 March 2015). [CrossRef]

6. Reed, M.S.; Stringer, L.C. Land Degradation, Desertification and Climate Change: Anticipating, Assessing and Adapting to Future Change; Routledge: Oxon, UK, 2016.

7. Emerson, K.; Nabatchi, T.; Balogh, S. An integrative framework for collaborative governance. J. Public Admin. Res. Theory 2012, 22, 1-29. [CrossRef]

8. Ansell, C.; Gash, A. Collaborative Governance in Theory and Practice. J. Public Admin. Res. Theory 2008, 18, 543-571. [CrossRef]

9. Susskind, L.; Rumore, D.; Hulet, C.; Field, P. Managing Climate Risks in Coastal Communities: Strategies for Engagement, Readiness and Adaptation; Anthem Press: London, UK, 2015; 464p, ISBN 978-1-78308-486-9.

10. Hossu, C.A.; Ioja, I.C.; Nita, M.R.; Hartel, T.; Badiu, D.L.; Hersperger, A.M. Need for a cross-sector approach in protected area management. Land Use Policy 2017, 69, 586-597. [CrossRef]

11. Brown, R.R.; Deletic, A.; Wong, T.H.F. Interdisciplinarity: How to catalyse collaboration. Nat. News 2015, 525, 315. [CrossRef] [PubMed]

12. United Nations Convention to Combat Desertification (UNCCD). Land Matters for Climate: Reducing the Gap and Approaching the Target; The Change Town Initiative: Bonn, Germany, 2015; p. 24. ISBN 978-92-95043-04-6. 
13. Imperial, M.T. Using Collaboration as a Governance Strategy: Lessons from Six Watershed Management Programs. Adm. Soc. 2005, 37, 281-320. [CrossRef]

14. Hossu, C.A.; Ioja, I.C.; Susskind, L.E.; Badiu, D.L.; Hersperger, A.M. Factors driving collaboration in natural resource conflict management: Evidence from Romania. Ambio 2018. [CrossRef] [PubMed]

15. Noroozi, J.; Akhani, H.; Breckle, S.W. Biodiversity and phytogeography of the alpine flora of Iran. Biodivers. Conserv. 2008, 17, 493-521. Available online: https://link.springer.com/article/10.1007/s10531007-9246-7 (accessed on 15 March 2014). [CrossRef]

16. Eriksen, S.H.; Kelly, P.M. Developing credible vulnerability indicators for climate adaptation policy assessment. Mitig. Adapt. Strateg. Glob. Chang. 2007, 12, 495-524. Available online: https://link.springer. com/article/10.1007/s11027-006-3460-6\#citeas (accessed on 3 March 2015). [CrossRef]

17. Kolahi, M.; Sakai, T.; Moriya, K.; Makhdoum, M.F. Challenges to the future development of Iran's Protected Areas system. Environ. Manag. 2012, 50, 750-765. Available online: https://link.springer.com/article/10. 1007/s00267-012-9895-5\#citeas (accessed on 17 February 2018). [CrossRef] [PubMed]

18. Ashrafi, K.; Shafiepour, M.; Ghasemi, L.; NajarAraabi, B. Prediction of climate change induced temperature rise in regional scale using neural network. Int. J. Environ. 2012, 6, 677-688. Available online: https: / /ijer.ut.ac.ir/article_538.html (accessed on 12 November 2017). [CrossRef]

19. Ekhtesasi, M.; Abdinejad, G.H.; Kosari, M.; Niazi, Y.; Tabatabaiee, S.A. Changing of climatic parameters: Alarming sign of desertification in Yazd. Jangal-o-Marta 2006, 74, 7-10. (In Persian)

20. Kousari, M.R.; Ekhtesasi, M.R.; Tazeh, M.; Saremi-Naeini, M.A.; Asadi-Zarch, M.A. An investigation of the Iranian climatic changes by considering the precipitation, temperature, and relative humidity parameters. Theor. Appl. Climatol. 2011, 103, 321-335. Available online: https://link.springer.com/article/10.1007/ s00704-010-0304-9\#citeas (accessed on 17 October 2016). [CrossRef]

21. Ahani, H.; Kherad, M.; Kousari, M.R.; van Roosmalen, L.; Aryanfar, R.; Hosseini, S.M. Nonparametric trend analysis of the aridity index for three large arid and semi-arid basins in Iran. Theor. Appl. Climatol. 2013, 112, 553-564. Available online: https://link.springer.com/article/10.1007/s00704-012-0747-2 (accessed on 11 January 2018). [CrossRef]

22. Marofi, S.; Sohrabi, M.M.; Mohammadi, K.; Sabziparvar, A.A.; Zare-Abyaneh, H. Investigation of meteorological extreme events over coastal regions of Iran. Theor. Appl. Climatol. 2011, 103, 401-412. Available online: https:/ /link.springer.com/article/10.1007/s00704-010-0298-3\#citeas (accessed on 11 March 2017). [CrossRef]

23. Raziei, T.; Daryabari, J.; Bordi, I.; Periera, L.S. Spatial patterns and temporal trends of precipitation in Iran. Theor. Appl. Climatol. 2014, 115, 531-540. Available online: https://link.springer.com/article/10.1007/ s00704-013-0919-8 (accessed on 17 May 2017). [CrossRef]

24. Kousari, M.R.; Ahani, H.; Hakimelahi, H. An investigation of near surface wind speed trends in arid and semiarid regions of Iran. Theor. Appl. Climatol. 2013, 114, 153-168. Available online: https:/ /link.springer. com/article/10.1007/s00704-012-0811-y\#citeas (accessed on 1 October 2017). [CrossRef]

25. Amiraslani, F.; Dragovich, D. Combating desertification in Iran over the last 50 years: An overview of changing approaches. J. Environ. Manag. 2011, 92, 1-13. Available online: https:/ /www.ncbi.nlm.nih.gov/ pubmed/20855149 (accessed on 14 March 2012). [CrossRef] [PubMed]

26. NAP. National Action Programme to Combat Desertification and Mitigate the Effects of Drought of Islamic Republic of Iran; The Forest, Rangeland and Watershed Management Organization: Tehran, Iran, 2004; p. 48. ISBN 964-6931-69-3. (In Persian)

27. Alijani, B.; O'Brien, J.; Yarnal, B. Spatial analysis of precipitation intensity and concentration in Iran. Theor. Appl. Climatol. 2008, 94, 107-124. Available online: https://link.springer.com/article/10.1007/ s00704-007-0344-y (accessed on 22 December 2017). [CrossRef]

28. Karger, D.N.; Conrad, O.; Böhner, J.; Kawohl, T.; Kreft, H.; Soria-Auza, R.W.; Zimmermann, N.E.; Linder, H.P.; Kessler, M. Climatologies at high resolution for the earth's land surface areas, 2017, Scientific Data 4, 170122. Available online: https:/ / www.nature.com/articles/sdata2017122 (accessed on 12 June 2018).

29. Karger, D.N.; Conrad, O.; Böhner, J.; Kawohl, T.; Kreft, H.; Soria-Auza, R.W.; Zimmermann, N.E.; Linder, H.P.; Kessler, M. Data from: Climatologies at high resolution for the earth's land surface areas, 2017, Dryad Digital Repository. Available online: https:/ / doi.org/10.5061/dryad.kd1d4 (accessed on 12 June 2018). 
30. Keshavarz, M.; Karami, E.; Zibaei, M. Adaptation of Iranian farmers to climate variability and change. Reg. Environ. Chang. 2014, 14, 1163-1174. Available online: https://link.springer.com/article/10.1007/ s10113-013-0558-8\#citeas (accessed on 16 October 2016). [CrossRef]

31. Dinpashoh, Y.; Jhajharia, D.; Fakheri-Fard, A.; Singh, V.P.; Kahya, E. Trends in reference crop evapotranspiration over Iran. J. Hydrol. 2011, 399, 422-433. Available online: https:/ /www.sciencedirect. com/science/article/pii/S0022169411000461 (accessed on 11 November 2016). [CrossRef]

32. Mullan, D. Soil erosion under the impacts of future climate change: Assessing the statistical significance of future changes and the potential on-site and off-site problems. Catena 2013, 109, 234-246. Available online: https://www.sciencedirect.com/science/article/pii/S0341816213000696 (accessed on 11 June 2014). [CrossRef]

33. Amiraslani, F.; Dragovich, D. Preliminary assessment of economic dimensions and benefits of fifty years anti-desertification plans in Iran. In Proceedings of the UNCCD Second Scientific Conference, Bonn, Germany, 9-12 April 2013.

34. United Nations Framework Convention on Climate Change (UNFCCC). Available online: http:/ / newsroom. uat.unfccc.int/media/495095/country-brief-iran.pdf (accessed on 1 December 2017).

35. Makhdoum, M.F. Management of protected areas and conservation of biodiversity in Iran. Int. J. Environ. Stud. 2008, 65, 563-585. Available online: https://www.tandfonline.com/doi/abs/10.1080/ 00207230802245898 (accessed on 9 December 2016). [CrossRef]

36. Amiraslani, F.; Dragovich, D. Cross-sectoral and participatory approaches to combating desertification: The Iranian experience. Nat. Resour. Forum 2010, 34, 140-154. Available online: https: / onlinelibrary.wiley. com/doi/abs/10.1111/j.1477-8947.2010.01299.x (accessed on 9 Januray 2010). [CrossRef]

37. Tahbaz, M. Environmental Challenges in Today's Iran. Iran. Stud. 2016, 49, 943-961. Available online: https: / www.tandfonline.com/doi/abs/10.1080/00210862.2016.1241624?journalCode=cist20 (accessed on 10 May 2018). [CrossRef]

38. Karimkoshteh, M.H.; Haghiri, M. Water-reform strategies in Iran's agricultural sector. Perspect. Glob. Dev. Technol. 2004, 3, 327-346. Available online: http:/ /booksandjournals.brillonline.com/content/journals / 10.1163/1569150042442511 (accessed on 7 April 2015). [CrossRef]

39. Strategic National Plan. Strategic National Plan for the Desert-Outlook 2025; Ministry of Agriculture: Tehran, Iran, 2008. (In Persian)

40. United Nations (UN). United Nations Technical Mission on the Drought Situation in the Islamic Republic of Iran; UN Office for the Coordination of Humanitarian Affairs: New York, NY, USA, 2000; p. 35.

41. Iran UNFCCC. Iran Second National Communication to UNFCCC; UNDP—Department of Environment: Iran, Tehran, 2010; 230p.

42. Abdinejad, G. Desert and desertification in Iran: Policies, programmes and outcomes. Jangal-o-Marta 2007, 74, 23-26. Available online: http:/ / www.frw.org.ir/00/En/ (accessed on 5 March 2015). (In Persian)

43. United Nations Development Programme (UNDP). Carbon Sequestration Project (CSP); United Nations: Tehran, Iran, 2011; p. 2.

44. Haghani, G.; Hojati, M. The study of plant species diversification in biological measures for combating desertification. Jangal-o-Marta 2006, 14, 71-75. (In Persian)

45. Hashemi, S.A.A.; Karimipour, H.; Jazi, H. Assessement of watershed management impact on erosion and sedimentation: Behvard watershed, Iran. Int. J. Dev. Res. 2015, 5, 4897-4904.

46. Ahmadi, H.; Heshmati, G.; Pesarakli, M.; Naseri, R.H. Comparison of carbon sequestration in organs of Haloxylon species: Case study: South Salt Lake. In Proceedings of the Fourth National Conference on Pasture and Ange Management in Iran, Tehran, Iran, 21 December 2017; Publication of Research Institute of Forestsand Rangelands: Tehran, Iran, 2017.

47. Manouchehri, G.R.; Mahmoodian, S.A. Environmental impacts of dams constructed in Iran. Int. J. Water Resour. Dev. 2002, 18, 179-182. Available online: https:/ /www.tandfonline.com/doi/abs/10.1080/ 07900620220121738?journalCode=cijw20 (accessed on 16 May 2014). [CrossRef]

48. Carle, J.; Vuorinen, P.; Del Lungo, A. Status and trends in global forest plantation development. For. Prod. J. 2002, 52, 1-13. Available online: http://www.fao.org/forestry/25856-0c773a78823b8b936c7f6c323919bd706.pdf (accessed on 21 October 2014).

49. Moameni, A. Impact of Land Utilization Systems on Agricultural Productivity; Asian Productivity Organization: Tehran, Iran, 2003; 291p, ISBN 92-833-7010-4. 
50. Khosrokhavar, F.; Ghaneirad, M.; Toloo, G. Institutional problems of the emerging scientific community in Iran. Sci. Technol. Soc. 2007, 12, 171-200. Available online: http://journals.sagepub.com/doi/pdf/10.1177/ 097172180701200201 (accessed on 28 March 2015). [CrossRef]

51. Koocheki, A.; Nasiri, M.; Kamali, G.A.; Shahandeh, H. Potential impacts of climate change on agroclimatic indicators in Iran. Arid Land Res. Manag. 2006, 2, 245-259. Available online: https:/ / www.tandfonline.com/ doi/abs/10.1080/15324980600705768 (accessed on 2 November 2016). [CrossRef]

52. Fanni, Z. Cities and urbanization in Iran after the Islamic revolution. Cities 2006, 23, 407-411. Available online: https://www.sciencedirect.com/science/article/pii/S0264275106000746 (accessed on 15 April 2018). [CrossRef]

53. Karbasioun, M.; Mulder, M.; Biemans, H. Changes and Problems of Agricultural Development in Iran. World. J. Agric. Sci. 2008, 4, 759-769. Available online: https:/ /www.researchgate.net/publication/37792164_ Changes_and_Problems_of_Agricultural_Development_in_Iran (accessed on 18 December 2016).

54. Abbaspour, M.; Faramarzi, M.; Seyed-Ghasemi, S.; Yang, H. Assessing the impact of climate change on water resources in Iran. Water Resour. Res. 2009, 45, 1-16. Available online: http:/ / onlinelibrary.wiley.com/doi/10. 1029/2008WR007615/full (accessed on 12 December 2016). [CrossRef]

55. Misra, M. Mobile pastoralists in Iran's arid lands. Int. J. Environ. Stud. 2009, 3, 357-370. Available online: https: / www.tandfonline.com/doi/abs/10.1080/00207230902752512 (accessed on 30 June 2016). [CrossRef]

56. Faramarzi, M.; Abbaspour, K.C.; Schulin, R.; Yang, H. Modelling blue and green water resources availability in Iran. Hydrol. Process. 2009, 23, 486-501. Available online: https:/ / onlinelibrary.wiley.com/doi/abs/10. 1002/hyp.7160 (accessed on 10 November 2016). [CrossRef]

57. Moradi, R.; Koocheki, A.; Nassiri-Mahallati, M. Adaptation of maize to climate change impacts in Iran. Mitig. Adapt. Strateg. Glob. Chang. 2013, 19, 1223-1238. Available online: https://link.springer.com/article/ 10.1007/s11027-013-9470-2\#citeas (accessed on 15 February 2018). [CrossRef]

58. Amiraslani, F.; Dragovich, D. Forest management policies and oil wealth in Iran over the last century: A review. Nat. Resour. Forum 2013, 37, 167-176. Available online: https:/ / onlinelibrary.wiley.com/doi/pdf/ 10.1111/1477-8947.12016 (accessed on 11 August 2013). [CrossRef]

59. Javaherian, Z.; Maknoon, R.; Abbaspour, M.; Moharamnejad, M. Investigating the impacts of global environmental evolutions on long-term planning of natural resources in Iran. Int. J. Environ Res. 2013, 7, 561-568. Available online: https://ijer.ut.ac.ir/article_636.html (accessed on 3 April 2015). [CrossRef]

60. Lerner, B. Available online: http://www.loc.gov/law/foreign-news/article/iran-law-to-protect-wetlands / (accessed on 15 September 2017).

61. Amiraslani, F.; Dragovich, D.; Caiserman, A. A long-term cost-benefit analysis of national anti-desertification plans in Iran. Desert 2018, 23, 25-35.

62. Mendelsohn, R. The impact of climate change on agriculture in developing countries. J. Nat. Resour. Policy Res. 2009, 1, 5-19. Available online: https://www.tandfonline.com/doi/full/10.1080/19390450802495882 (accessed on 28 August 2014). [CrossRef]

63. Sherwood, A. Community adaptation to climate change: Exploring drought and poverty traps in Gituamba location, Kenya. J. Nat. Resour. Policy Res. 2016, 5, 141-161. Available online: https: / www.tandfonline.com/ doi/abs/10.1080/19390459.2013.811857?journalCode=rjnr20 (accessed on 20 June 2017). [CrossRef]

(C) 2018 by the authors. Licensee MDPI, Basel, Switzerland. This article is an open access article distributed under the terms and conditions of the Creative Commons Attribution (CC BY) license (http://creativecommons.org/licenses/by/4.0/). 